\title{
Jubileusz 100 lat Archiwum Państwowego w Lublinie (1918-2018)
}

W roku 2018 świętujemy jubileusz 100-lecia powstania Archiwum Państwowego w Lublinie. W tych szczególnych dniach chętnie odwołujemy się do kart z dziejów Archiwum, sięgając do różnego rodzaju źródeł i korzystając z ludzkiej pamięci. W ten sposób staramy się pokazać godne uwagi wydarzenia, poznać ważne zjawiska, zaprezentować liczący się dorobek na różnych obszarach działalności i przywołać we wspomnieniach dawnych pracowników. Ożywiając przeszłość chcemy też lepiej zrozumieć dzień dzisiejszy, co pozwala nam z większą pokorą, ale i ufnością spoglądać w przyszłość. W tym miejscu przypomnijmy tylko wybrane fakty z bogatej historii lubelskiego Archiwum, które lepiej pozwalają wyobrazić sobie drogę jaką przeszło ono w ciągu pierwszych stu lat swego istnienia.

Lubelskie Archiwum powstało w 1918 r., ale drogę do niego wyznaczały jeszcze wcześniejsze działania okupacyjnych władz austriackich i Tymczasowej Rady Stanu Królestwa Polskiego z lat I wojny światowej, które były związane z zabezpieczeniem dokumentacji pozostałej po władzach i urzędach rosyjskich. Początek dał mu reskrypt Rady Regencyjnej z 31 VII 1918 r. o archiwach państwowych i opiece nad archiwaliami, który powołał do życia pięć archiwów w Warszawie i trzy archiwa miejscowe, w tym w Lublinie. Faktycznie rozpoczęło swoją działalność 1 XII 1918 r. po objęciu stanowiska dyrektora przez przybyłego z Petersburga Stanisława Ptaszyckiego, już wówczas profesora Uniwersytetu Lubelskiego (dzisiejszego KUL).

Utworzenie Archiwum Państwowego w Lublinie było faktem o trwałym znaczeniu. Jego miejsce na mapie archiwalnej niepodległej Polski potwierdził dekret o organizacji archiwów państwowych i opiece nad archiwaliami z 7 II 1919 r., wydany przez Naczelnika Państwa Józefa Piłsudskiego. Od tamtego czasu lubelskie Archiwum działa nieprzerwanie aż do dnia dzisiejszego, pomimo 
zmian państwowości i ustrojów politycznych. Z racji swej metryki należy do jednych z pierwszych archiwów państwowych w Polsce, jest też jedną z najstarszych instytucji publicznych Lublina i Lubelszczyzny o ciągłej historii.

Przy okazji naszego jubileuszu warto pamiętać, że tradycje archiwalne Lublina były znacznie starsze i choć nie miały bezpośredniego wpływu na powstanie archiwum państwowego w 1918 r., to jednak z jego historią są nierozerwalnie związane. Sięgały one zapewne średniowiecza, ale lepiej znane są dopiero od XVI w. Lublin tego czasu był siedzibą władz miejskich oraz urzędów i sądów szlacheckich, w tym Trybunału Koronnego. Do końca I Rzeczypospolitej działały w mieście trzy archiwa, w których przechowywano dokumenty i księgi miejskie, księgi grodu lubelskiego oraz księgi lubelskich sesji Trybunału Koronnego, księgi ziemskie i podkomorskie lubelskie. Nowy rozdział w dziejach lubelskich archiwów jest związany z utworzeniem w Lublinie w 1827 r. Archiwum Akt Dawnych, pierwszego $\mathrm{w}$ mieście archiwum historycznego, które niezwiązane z żadnym na bieżąco działającym urzędem, miało przechowywać dawne akta z terenu Lubelszczyzny. W jego zasobie znalazły się księgi sądów i urzędów szlacheckich oraz księgi i przywileje miast, a także początkowo księgi Trybunału Koronnego. Działało tylko 60 lat - w 1887 r. zostało zlikwidowane, a jego zasób w całości przewieziono nie do Warszawy, jak w przypadku innych likwidowanych w Królestwie Polskim w tym samym czasie archiwów akt dawnych, tylko do Wilna, bowiem uznano, że dotyczy przeszłości „ziem rosyjskich”. W ten sposób gubernialny Lublin na 40 lat został pozbawiony zarówno historycznego zasobu, jak i archiwum. Niezależnie od losów akt ważnym rezultatem działalności Archiwum Akt Dawnych w Lublinie było pojawienie się wykwalifikowanych pracowników, którzy otwierają poczet lubelskich archiwistów. Do ich grona należeli m.in. Piotr Zagrobski, Jan z Dukli Roman i Józef Detmerski.

Dekret Naczelnika Państwa z 7 II 1919 r. stworzył ramy prawne działalności archiwów państwowych w Polsce, które obowiązywały do końca II Rzeczypospolitej. Archiwum Państwowe w Lublinie w tym czasie zbudowało swoją trwałą pozycję, choć od samego początku musiało borykać się z wieloma, często podstawowymi, problemami. Początkowo jego zasób tworzyły akta XIX-wieczne, w tym głównie gubernialnych i powiatowych rosyjskich urzędów administracyjnych, skarbowych, włościańskich, wojskowych, żandarmerii z terenów guberni lubelskiej, chełmskiej i częściowo siedleckiej. Najważniejszym osiągnięciem młodego archiwum było odzyskanie zasobu staropolskiego, który w znacznej części powrócił z Wilna do Lublina już jesienią 1919 r. Losy akt staropolskich wyznaczają ciągłą linię tradycji archiwalnej naszego miasta od momentu ich wy- 
tworzenia, przez dzieje ich przechowywania z zasobie dziewiętnastowiecznego Archiwum Akt Dawnych aż do zgromadzenia w nowo utworzonym Archiwum Państwowym w Lublinie. Do dziś stanowią skarb i chlubę lubelskiego Archiwum.

Z lubelskim Archiwum od samego początku były związane wybitne postaci archiwistów i historyków. Na samym początku na krótko związali się z nim Józef Seruga i Piotr Bańkowski, ale swój charakter zawdzięczało dwóm pierwszym dyrektorom - Stanisławowi Ptaszyckiemu i od 1926 r. Leonowi Białkowskiemu. Z pracujących $\mathrm{w}$ tamtym czasie archiwistów szczególne miejsce przypadło kustoszowi Janowi Riabininowi, autorowi wielu cenionych pomocy archiwalnych i publikacji z zakresu regionalnej historii, laureatowi nagrody miasta Lublina. Wspomnieć też należy Aleksandra Kossowskiego, znawcę historii nowożytnej i profesora KUL oraz Władysława Adamczyka, badacza historii gospodarczej i pierwszego dyrektora Archiwum Państwowego w Olsztynie.

W czasie II wojny światowej Archiwum nie przerwało swojej działalności. Włączone w struktury władz dystryktu lubelskiego podlegało szefowi niemieckiego Urzędu Archiwalnego (Archivamt). Nadal pracował w nim polski, w większości przedwojenny personel. Po wyzwoleniu spod okupacji niemieckiej Archiwum oficjalnie rozpoczęło działalność 27 VII 1944 r. Przed pracownikami stanął palący problem zabezpieczenia dokumentacji wytworzonej przez administrację niemiecką, której ewakuujący się w pośpiechu Niemcy nie zdążyli zniszczyć. Udało się wówczas zabezpieczyć i włączyć do zasobu akta administracji obozu koncentracyjnego na Majdanku, więzienia na Zamku, gestapo, żandarmerii i gubernatora dystryktu lubelskiego. Przez pierwsze powojenne lata kierowanie Archiwum zostało ponownie powierzone L. Białkowskiemu, którego osoba stała się swoistym zwornikiem między dawnymi i nowymi czasami.

W powojennej rzeczywistości polityczno-ustrojowej następowały zmiany w strukturze organizacyjnej i zasobie Archiwum. Zmieniona została jego nazwa na Wojewódzkie Archiwum Państwowe w Lublinie, powstały podlegające mu archiwa powiatowe w Chełmie, Łukowie, Zamościu i Kraśniku, które gromadziły głównie archiwalia powojenne, zgodnie z określoną właściwością terytorialną. Ukształtowany po II wojnie światowej zasięg terytorialny działalności Archiwum obejmował obszar województwa lubelskiego, do którego należały historyczne ziemie położone pomiędzy Wisłą, Bugiem i Sanem. Po II wojnie światowej dość szybko zaczął także powiększać się zasób Archiwum. Wzrósł znacząco po włączeniu samodzielnego do $1950 \mathrm{r}$. archiwum miejskiego w Lublinie oraz po przejęciu archiwów, likwidowanych w wyniku reform ustrojowych, prywatnych 
zakładów przemysłowych i własności ziemskiej. Cenny dopływ stanowiły oczywiście XVI-wieczne księgi ziemskie, grodzkie i miejskie z dawnego zasobu Archiwum Akt Dawnych, rewindykowane z ZSRR w 1962 r. Z kolei nowe przepisy prawne zapewniały Archiwum stały dopływ akt $\mathrm{z}$ różnych urzędów i instytucji, ale też obligowały archiwistów do kształtowania przyszłego zasobu przez systematyczny nadzór nad składnicami akt (archiwami zakładowymi) oraz instruktaż w zakresie poprawnej organizacji pracy kancelarii, zwłaszcza wprowadzania coraz powszechniej jednolitych wykazów akt.

W 1965 r. Archiwum przeniosło się do nowej siedziby położonej w obrębie Starego Miasta, w odbudowanym po wojennych zniszczeniach zabytkowym gmachu byłego kolegium jezuickiego. Do dziś zajmuje to godne i rozpoznawalne miejsce w samym rogu placu katedralnego między dostojną bryłą katedry i wysmukłą sylwetą Wieży Trynitarskiej. Stąd już od ponad pół wieku dobrze strzeże dziedzictwa dokumentacyjnego i archiwalnego Lublina oraz znacznej części województwa lubelskiego.

W latach 70. XX w. nastąpiły w historii Archiwum kolejne ważne zmiany strukturalne i organizacyjne. Reforma administracyjna kraju z 1975 r. doprowadziła do przekształcenia Archiwum Powiatowego w Zamościu, będącego dotychczas lokalną strukturą Wojewódzkiego Archiwum Państwowego w Lublinie, w samodzielne archiwum szczebla wojewódzkiego, natomiast archiwa powiatowe w Chełmie, Kraśniku i Radzyniu Podlaskim (to ostatnie przeniesione z Łukowa) zostały oddziałami terenowymi (nazywane obecnie zamiejscowymi) lubelskiego Archiwum. Nowy podział administracyjny kraju wprowadzony w 1999 r. nie spowodował już dalszych zmian w strukturze i zasięgu właściwości terytorialnej Archiwum, które od 1983 r. powróciło do swej pierwotnej nazwy - Archiwum Państwowe w Lublinie. Dziś działa ono na terenie przeważającej części województwa lubelskiego (poza powiatami: biłgorajskim, tomaszowskim, zamojskim i janowskim) oraz na niewielkiej części województwa mazowieckiego (powiat łosicki).

Dokonujące się po 1989 r. przemiany polityczno-ustrojowe, gospodarcze i społeczne zaowocowały znów poważnym wzrostem zasobu. W 1990 r. przejęto archiwalia struktur organizacyjnych Polskiej Zjednoczonej Partii Robotniczej i organizacji młodzieżowych, rozpoczął się wówczas także proces przejmowania akt prywatyzowanych zakładów pracy.

Obecnie zasób lubelskiego Archiwum należy do jednych z najcenniejszych pod względem historycznym i największych ilościowo, zgromadzonych w polskich archiwach państwowych. W końcu 2018 r. znajdowało się w nim oko- 
ło 13,5 km akt uformowanych w blisko 1400000 jednostek inwentarzowych i uporządkowanych w 4144 zespoły archiwalne. Najstarsze akta pisane na pergaminie pochodzą z XIV w., natomiast najnowsze materiały, w tym dokumenty elektroniczne, już z początku obecnego stulecia.

W powojennej historii z lubelskim Archiwum było związanych wiele osób, które na trwale zapisały się w jego dziejach, a nawet szerzej, w dziejach polskiej archiwistyki i historiografii. Wśród nich wymienić należy Mirosławę Zakrzewską-Dubasową, dyrektora Archiwum w latach 1949-1954 i późniejszego profesora Uniwersytetu Marii Curie-Skłodowskiej; Tadeusza Mencla, dyrektora Archiwum w latach 1955-1961 i późniejszego profesora UMCS; dr Marię Trojanowską, dyrektora Archiwum w latach 1991-1993 oraz dr Elżbietę Wierzbicką, dyrektora Archiwum w latach 1994-2001. Na osobną wzmiankę zasługuje Franciszek Cieślak, który aż przez 27 lat kierował Archiwum w latach 1961-1988, tworząc mocne podstawy jego wielostronnej działalności. Z licznego grona pracowników starszego pokolenia wspomnieć trzeba Kazimierę Gawarecką, Julię Godlewską, Stanisławę Paulową, Marię Stankową, Danutę Wójcik-Góralską, Annę Pawłowską-Wielgus, Stefana Janickiego, Henryka Sadaja, Józefa Tomczyka i Wojciecha Zyśkę. Z młodszego pokolenia, obecnie emerytowanych już pracowników, zapamiętamy przede wszystkim - Janinę Kosonowską, Jadwigę Krasnodębską, Ewę Kus, Józefa Kusa, Stanisława Minickiego, Tadeusza Surdackiego, Marię Trojanowską i Ludwika Zabielskiego. Przez krótszy czas z Archiwum byli związani późniejsi uczeni uniwersyteccy - Zbigniew Góralski, Wiesław Śladkowski, Janusz Łosowski i Marek Konstankiewicz lub pracownicy i archiwiści innych instytucji - Rober Kuwałek, Anna Łosowska, Bożenna Janocińska, Leon Popek i Grażyna Suszycka-Tomkiewicz. Dla wielu użytkowników pracowni naukowej lubelskie Archiwum będzie się kojarzyć głównie z osobą Anny Widomskiej, która mając bogatą wiedzę o jego zasobie, była nieocenioną pomocą przy różnego rodzaju poszukiwaniach archiwalnych. Dzisiaj Archiwum zatrudnia 60 pracowników, wielu z nich, podobnie jak ich poprzednicy, z racji swoich osiągnięć archiwalnych i badawczych ma szansę zapisać się na trwałe w jego dziejach. O nich będzie się wspominać przy okazji kolejnego jubileuszu.

W ostatnich dwóch dekadach pojawiły się nowe wyzwania, które miały w istotny sposób wyznaczyć kierunki działania archiwów państwowych w Polsce, w tym także lubelskiego ośrodka. Postępujące od początku lat 90. ubiegłego wieku zmiany polityczne i ustrojowe w Polsce wywarły także wpływ na działalność archiwów, które uczestnicząc w budowie społeczeństwa demokratycznego, stawały się coraz bardziej otwarte i przyjazne dla użytkowni- 
ków. Procesowi temu towarzyszyło także inne ważne zjawisko polegające na kształtowaniu społeczeństwa informacyjnego, którego podstawowymi wyznacznikami są: dostęp do informacji, uznanie strategicznego znaczenia informacji oraz rozwój technologii cyfrowej i telekomunikacyjnej. Lubelskie Archiwum aktywnie włączyło się w zachodzące zmiany, uczestnicząc jako jedno $\mathrm{z}$ pierwszych $\mathrm{w}$ pracach nad wdrożeniem systemu Zintegrowanego Systemu Informacji Archiwalnej (ZoSIA) i podejmując szeroko zakrojony program digitalizacji materiałów archiwalnych oraz ich udostępniania w Internecie. Dla użytkowników efekty obu tych działań są widoczne w trakcie korzystania z ogólnopolskiego serwisu szukajwarchiwach.pl, na którym Archiwum do końca 2018 r. udostępniło prawie 4 miliony skanów materiałów archiwalnych z własnego zasobu. W ostatnich latach archiwa państwowe szeroko rozwinęły działalność edukacyjną, traktując ją jako formę popularyzacji wiedzy o archiwach i zasobie archiwalnym. Także archiwum lubelskie stworzyło bogatą i ciekawą ofertę skierowaną do różnych grup odbiorców, w tym głównie do uczniów i studentów. Dużym zainteresowaniem cieszy się cykliczny program „Archiwa rodzinne”.

Po stu latach nieprzerwanego istnienia można powiedzieć, że z racji pełnionych funkcji i zadań Archiwum Państwowe w Lublinie jest instytucją podobną do innych archiwów państwowych, jednak z uwagi na posiadany zasób o unikatowym charakterze jest placówką niepowtarzalną. Jako urząd administracji publicznej zarządza dokumentacją o historycznym znaczeniu. W ramach działalności archiwalnej gromadzi, przechowuje, zabezpiecza, opracowuje i w końcu udostępnia archiwalia zainteresowanym osobom. Archiwum realizuje też politykę w zakresie tzw. narastającego zasobu archiwalnego, a więc dba o to, aby dokumentacja obecnie wytwarzana przez różne jednostki organizacyjne była właściwie oceniona pod względem jej wartości historycznej i przygotowana do wieczystego przechowywania. Prowadzi też działalność informacyjną, wykorzystując do tego najnowsze technologie i narzędzia informatyczne. Aktywnie działa w zakresie popularyzacji wiedzy o archiwum i jego zasobie, promując kulturę archiwalną i historyczną.

Cała dotychczasowa historia oraz realizowane współcześnie działania czynią z Archiwum Państwowego w Lublinie instytucję szczególną dla zachowania szerokiego dziedzictwa kulturowego Lubelszczyzny. Stoi na straży niepowtarzalnego dziedzictwa dokumentacyjnego od jego pierwszych wytworów kancelarii średniowiecznych, przez wszystkie następne stulecia, aż do produkcji kancelaryjnej dzisiejszych aktotwórców. Dzięki temu możliwe jest poznawanie przeszłości państwa, regionu, społeczeństwa i społeczności oraz poszczególnych osób. 
Archiwum Państwowe w Lublinie z uwagi na bogatą i ciekawą historię niewątpliwie zasługuje na swoją monografię. Niestety nie udało się takiej pracy przygotować na jubileusz 100-lecia, można jednak ufać, że powstanie w przyszłości, napisana przez ciekawego jej dziejów autora. Drogę do tego celu znaczą coraz liczniejsze publikacje o historii i współczesności Archiwum, która także szybko staje się najpierw bliską, a później coraz dalszą przeszłością. Wiele dotychczasowych prac zostało poświęconych opisaniu zasobu i poszczególnych zabytków archiwalnych. Powyższy jubileuszowy tekst niech stanie się zachętą do podjęcia bardziej systematycznych badań nad historią Archiwum.

Tymczasem publikacją uświetniającą jubileusz 100-lecia Archiwum Państwowego w Lublinie jest tom 5 „Studiów Archiwalnych”, w którym pod osobnym tytułem zostało zamieszczonych pięć artykułów przybliżających bardziej wnikliwie historię i działalność Archiwum. Kolejne teksty zostały poświęcone poszczególnym strukturom Archiwum, osobno lubelskiej centrali w latach 1944-1989, a osobno Archiwum Powiatowemu w Zamościu i pozostałym archiwom powiatowym, później oddziałom zamiejscowym w Chełmie, Kraśniku i Radzyniu Podlaskim (pierwotnie w Łukowie) od czasu ich powstania w latach 50. XX w. aż do dziś. Artykuły te są pierwszymi próbami bardziej syntetycznego spojrzenia na historię poszczególnych placówek lubelskiego Archiwum. 